\title{
HEAT TRANSFER DETERMINED BY THE TEMPERATURE SENSITIVE PAINT METHOD
}

\author{
Łukasz Jeziorek, Krzysztof Szafran, Paweł Skalski \\ Instytut Lotnictwa, EDC, CTKE \\ 02-256 Warszawa al. Krakowska 110/114 \\ Jeziorek.Lukasz@o2.pl; Krzysztof.Szafran@ilot.edu.pl; Pawel.Skalski@ilot.edu.pl
}

\begin{abstract}
The paper presents practical aspects of determining the amount of heat flow by measuring the distribution of surface temperature using the Temperature Sensitive Paint (TSP) method. The quantity measured directly with TSP is the intensity of the excited radiation, which is then converted to surface temperature. The article briefly presents three different methods for determining the heat transfer coefficient. Each of these methods is based on a separate set of assumptions and significantly influences the construction of the measuring station. The advantages of each of the presented methods are their individual properties, allowing to improve accuracy, reduce the cost of testing or the possibility of using them in tests of highly complex objects. For each method a mathematical model used to calculate the heat transfer coefficient is presented. For the steady state heat transfer test method that uses a heater of constant and known thermal power, examples of the results of our own research are presented, together with a comparison of the results with available data and a discussion of the accuracy of the results obtained.
\end{abstract}

Keywords: temperature sensitive paint, TSP, temperature measurement, heat transfer coefficient, HTC.

\section{INTRODUCTION}

The method of measurement with temperature sensitive paint consists in determining the surface temperature by measuring the radiation emitted by excited temperature sensitive paint $[1,2]$. The excitation is performed by means of LEDs, lamps emitting specific wavelengths or laser [3]. This method requires calibration, which is carried out in calibration chambers with strictly controlled temperature $[4,5]$. Due to the much higher resolution than the measurement techniques used in the past and the lack of instrumentation of the tested object, this technique is perfectly suited to examine objects that have been difficult to test so far. A good example may be rotating elements of flow machines, such as rotors of compressors, similarly as propellers, windmills and ducted fans $[6,7,8]$. Temperature measurements are 
of great importance in experimental aerodynamics, as they are perfect for determining the place of the boundary layer transition $[9,10]$. Another area of application of this method are measurements of heat exchange intensity on the surface of hypersonic airplanes, rockets, space capsules [11]. Temperature sensitive paint was also widely used in the study of machine parts cooling, both by means of a cooling film $[12,13]$, as well as by means of jets impinging the cooled surface $[14,15]$.

The technique of measuring the surface temperature of solids with the use of temperature sensitive paint has already become a standard technique used on an equal footing with infrared thermography $[16,17]$. Temperature sensitive paint can be used wherever an infrared camera is unable to reach, due to the use of materials such as glass or acrylic glass, which are opaque to infrared rays in the model construction. The temperature is then measured by a high quality RGB camera that captures visible light, perfectly permeable through window glass or acrylic glass.

In heat flow studies, which are essential for the design of thermal devices, temperature measurement is not the most important parameter to be determined. Much more important than this is the measurement of the amount of heat flowing (heat flux) through the boundary of solid and gaseous phases. This measurement boils down to the determination of the heat transfer coefficient, or, more generally, to the determination of the Nusselt number for the flow described by the dimensionless quantities.

\section{DETERMINATION OF THE HEAT TRANSFER COEFFICIENT}

\subsection{Method using a surface heat source}

In the method using a surface heat source, the surface temperature is measured on a very thin layer of conductive material, but with a relatively high specific resistance [18] (e.g. Inconel alloys). The current flow causes the release of heat depending on the surface material resistance and current intensity. This method can be applied to very well for flat surfaces, where with a very low error rate it can be considered that a thin foil is evenly heated by the current flow.

Cooling of such heated surface will lead to a state in which on each infinitively small piece of surface the stream of heat emitted and taken over by the flow will be equal. In this state, the lower the heat transfer coefficient, the higher the temperature will be and vice versa

The formula for Nusselt's number in this case is in the form (21):

$$
N u=\frac{\eta \cdot U \cdot I \cdot d}{A \cdot\left(T_{\text {surface }}-T_{\text {flow }}\right) \cdot k}
$$

where:

A [m2] - heating foil area

$\mathrm{d}[\mathrm{m}]$ - reference dimension

$\mathrm{k}[\mathrm{W} / \mathrm{m}-\mathrm{K}]$ - thermal conductivity of the cooling medium (e.g. air)

I $[A]$ - electric current, flowing in the heater circuit

$\mathrm{T}_{\text {surface }}[\mathrm{K}]$ - solid surface temperature

$\mathrm{T}_{\text {flow }}[\mathrm{K}]$ - flow temperature, measured at the outlet from the nozzle

$\mathrm{U}[\mathrm{V}]$ - voltage between the edge of the heating foil

$\eta[-]$ - electric efficiency of the heater 
Fig. 1 shows the temperature distribution in the test model.

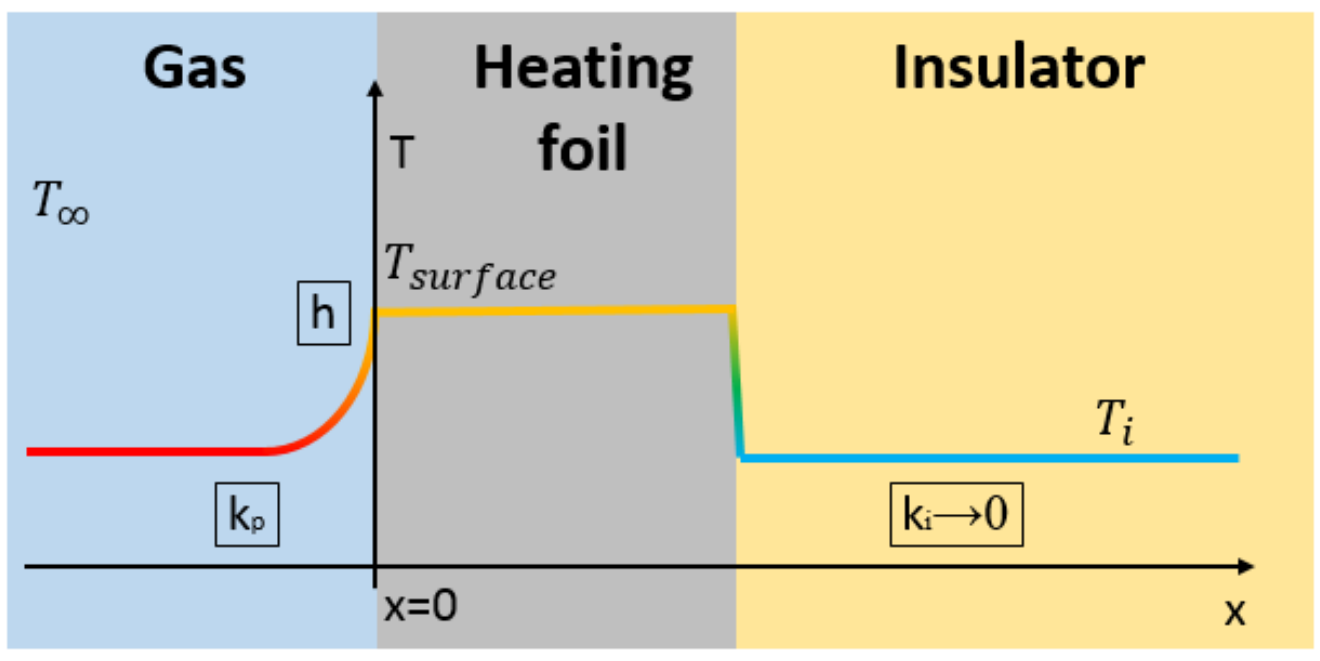

Fig. 1 Temperature distribution in a test model equipped with a heating foil

\subsection{Method using a high thermal conductivity core}

In the method using a core with high thermal conductivity, temperature measurement is carried out on a relatively thin layer of insulator, which covers the core of the model with very high thermal conductivity [19]. This method can be successfully used for testing objects of complex shapes, e.g. tests of various objects in a wind tunnel.

Assuming that the core of the model with high thermal conductivity has a constant temperature, the distribution of temperature on the surface of the insulator is correlated with the heat flux per unit area according to relation (2):

$$
\dot{q}=\frac{k_{i}}{l} \cdot\left(T_{\text {surface }}-T_{\text {core }}\right)
$$

where:

$1[\mathrm{~m}]$ - thickness of insulator layer

$\mathrm{ki}[\mathrm{W} / \mathrm{mK}]$ - thermal conductivity of the insulator

$\mathrm{q}^{\cdot}[\mathrm{W} / \mathrm{m} 2]-$ heat flux density

The Nusselt's number for this model can be expressed by the formula (3):

$$
N u=\frac{d \cdot k_{i}}{l \cdot k_{p}} \cdot \frac{\left(T_{\text {surface }}-T_{\text {core }}\right)}{\left(T_{\text {surface }}-T_{\text {flow }}\right)}
$$

where:

$\mathrm{kp}[\mathrm{W} / \mathrm{mK}]$ - thermal conductivity of the cooling medium (e.g. air)

$\mathrm{T}_{\text {core }}[\mathrm{K}]$ - temperature of the core with a high thermal conductivity 
Fig. 2 shows the temperature distribution in a test model with a core of high thermal conductivity. a solid with high thermal conductivity

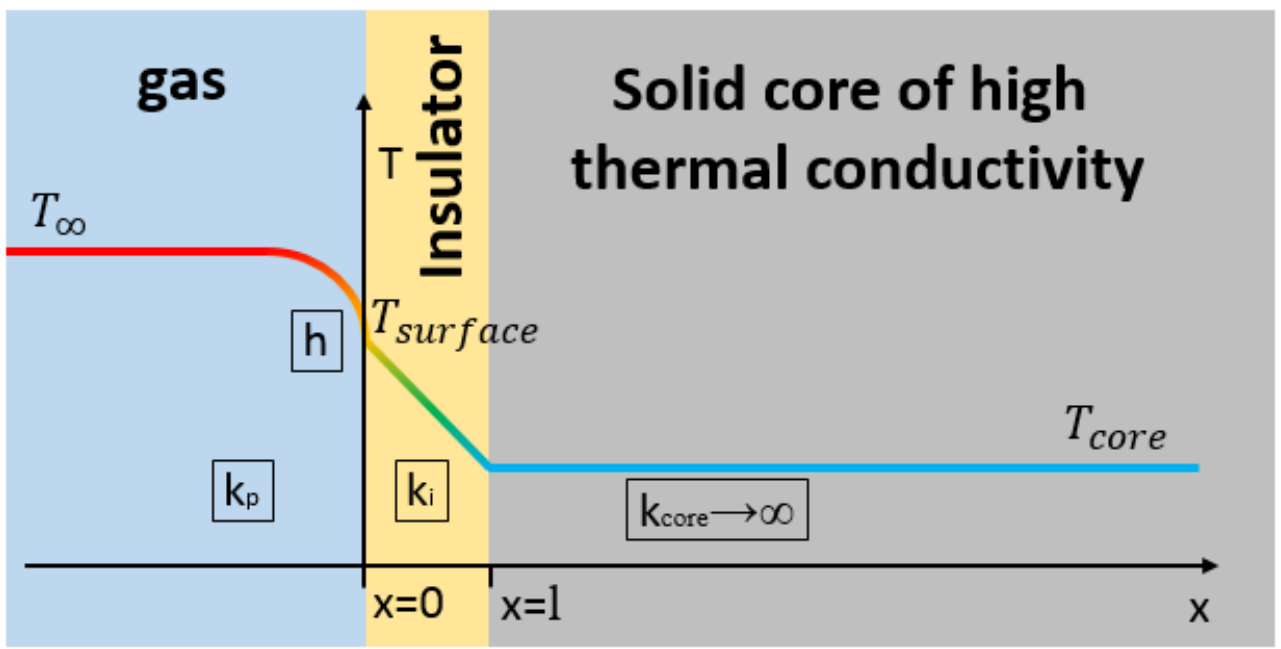

Figure 2: Temperature distribution in a test model with a high thermal conductivity core covered with an insulator layer

\subsection{Method of measuring the time-varying surface temperature}

The method of measuring the temperature of the surface variable in time is called Cook-Feldermann [20]. A one-dimensional case of heat conduction for a semi-finite solid is shown in Fig. 3. At its boundary, at the point of contact with a gaseous or liquid phase, the body exchanges heat with a fixed temperature medium $\mathrm{T}_{\infty}$ with a heat transfer coefficient $\mathrm{h}$. The initial temperature of the solid is $\mathrm{T}_{\mathrm{i}}$ and its density and specific heat are $\rho$ and $\mathrm{c}_{\mathrm{p}}$ respectively.

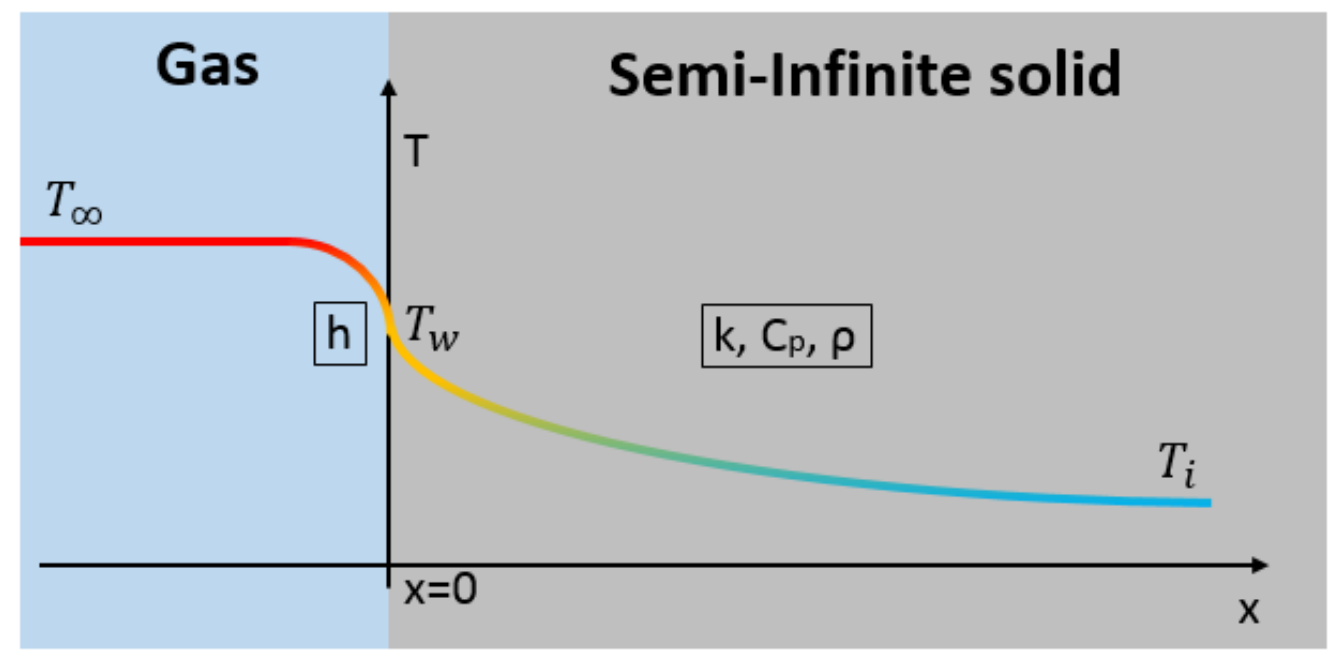

Fig. 3: Semi-finite solid exchanging heat with the gaseous medium. 
The analytical solution for semi-finite solid surface temperature is in the form (4):

$$
T_{w}(t)=T_{0}+\left(T_{\infty}-T_{0}\right) \cdot\left(1-e^{\frac{h^{2} \cdot \alpha \cdot t}{k^{2}}} \cdot \operatorname{erfc}\left(\frac{h \cdot \sqrt{\alpha \cdot t}}{k}\right)\right)
$$

where:

$\mathrm{h}[\mathrm{W} / \mathrm{m} 2-\mathrm{K}]$ - heat transfer coefficient

$\mathrm{t}[\mathrm{s}]$ - time counted from the beginning of solid heating,

$\mathrm{T}_{0}[\mathrm{~K}]$ - solid initial temperature

$\mathrm{T}_{\mathrm{w}}[\mathrm{K}]$ - solid surface temperature

$\mathrm{T}_{\infty}[\mathrm{K}]$ - temperature of flow, that is heating the solid

$\alpha=\frac{k}{\rho \cdot c_{p}}[\mathrm{~m} 2 / \mathrm{s}]-$ thermal diffusivity of the solid

$\operatorname{erfc}(x)=\frac{2}{\pi} \cdot \int_{x}^{\infty} e^{-t^{2}} d t-$ a complementary error function.

The solution to the time-dependent temperature distribution in the semi-finite solid can also be determined using a simple numerical model. Using the FTCS diagram (Forward-Time Central-Space), we obtain a numerical differential formula for temperature (5), (6):

$$
T_{i}^{n+1}=T_{i}^{n}+r \cdot\left(T_{i+1}^{n}-2 \cdot T_{i}^{n}+T_{i-1}^{n}\right)
$$

where:

$T_{i}^{n}[\mathrm{~K}]$ - temperature in the $\mathrm{i}$-th mesh node at time step $\mathrm{n}$

$$
\text { For: } r=\frac{\alpha \cdot \Delta t}{\Delta x^{2}} \leq \frac{1}{2} \text { (von Neumann's stability condition) }
$$

The temperature distribution obtained and the variation in surface temperature over time are illustrated by the following diagrams shown in Figure 4 and Figure 5. Figure 4 shows the temperature isolines in the semi-finite solid, where the body boundary is on the left and the isolines are plotted every 30 seconds. Fig. 5 shows the time dependency of the surface temperature at the point of jet impact (at the semi-infinite solid boundary). It is an analytical solution, marked in green in the graph and numerical solutions marked in red. 


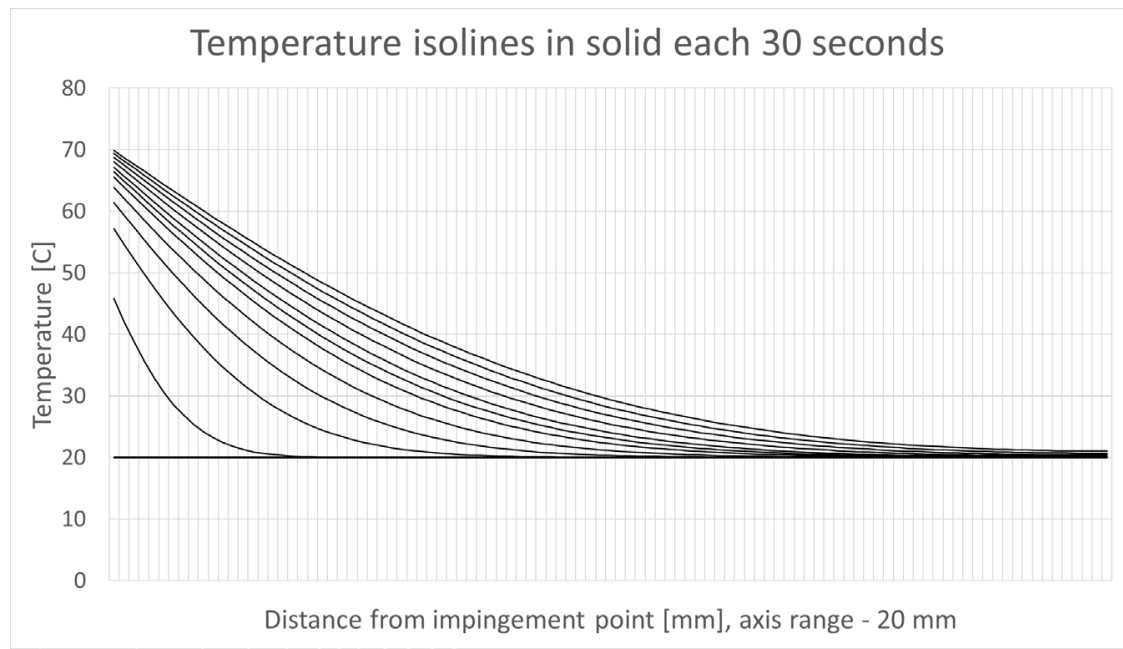

Fig. 4 Temperature isolines in a semi-finite solid

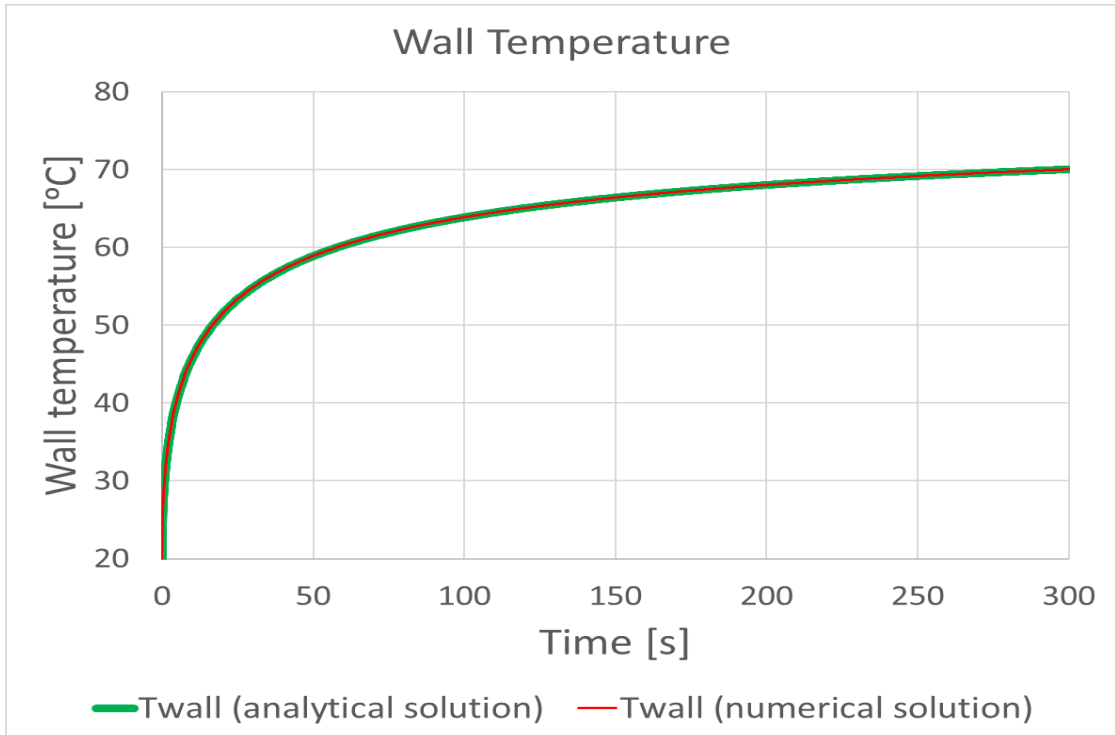

Figure 5: Temperature at the point of impact of the jet, at the boundary of a semi-finite solid

The above presented physical model for a semi-finished medium is unrealisable in laboratory practice, because the real elements have a finite thickness. In fact, measurements of Nusselt's number and heat conduction coefficient are possible during the time shorter than the so-called penetration time. This is the time after which the temperature on the other side of the wall changes by $1 \mathrm{~K}$ in relation to the ambient temperature. For example, for an acrylic glass wall with a thickness of $20 \mathrm{~mm}$ and a thermal conductivity of $\mathrm{k}=0.18 \mathrm{~W} / \mathrm{m}^{2}-\mathrm{K}$, the penetration time is approximately 4.5 minutes.

The use of this method in laboratory practice requires using material with low thermal conductivity, so that the increase in surface temperature over time can be accurately measured. Materials such as acrylic glass, polyamide or polyacetal are well suited for this purpose. 


\section{TEST RESULTS USING THE SURFACE HEATING SOURCE METHOD}

\subsection{Description of the test bench}

Within the project entitled "Development of TSP methodology (Temperature Sensitive Paint) and the potential of laboratory tests related to it". [21], which was designed to familiarize with the TSP measurement technique, a series of tests was carried out to cool the heating film using 25 air streams (arranged in a square matrix of $5 \times 5$ ). The test took place at atmospheric pressure. The test stand consisted of a perforated plate in which 25 holes of $6.25 \mathrm{~mm}$ diameter were drilled and a heating foil placed above the plate, which was hit by the air jets produced by the plate. The air flow was from the bottom to the top. The heating foil could be supported from above with an acrylic screen (transmitting visible light), it could also be unsupported. On its upper side it was painted with a thin layer of temperature sensitive paint. The perforated plate was supplied with air from underneath (the whole plate was placed on a universal air supply vessel, equipped with honeycomb mesh ensuring uniformity of the flow. The schematic diagram of the test stand is shown in Fig. 6. Fig. 7 shows a picture of a perforated plate with cooling holes mounted on a universal air supply vessel.

The quantity determined in the experiment is the surface temperature, which was determined on the basis of the brightness of light emitted by temperature sensitive paint.

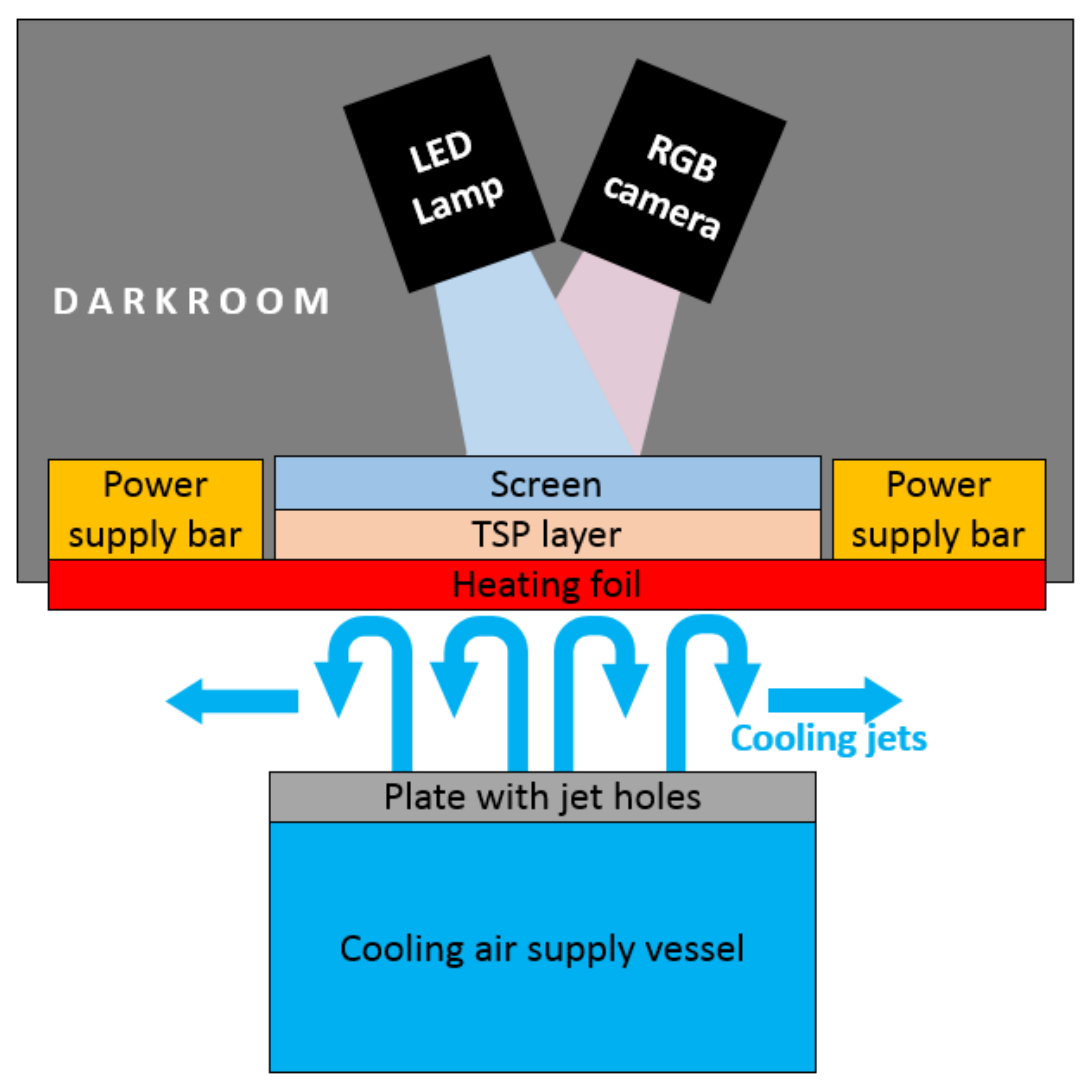

Fig. 6 Schematic diagram of the most important functional elements of the test stand 


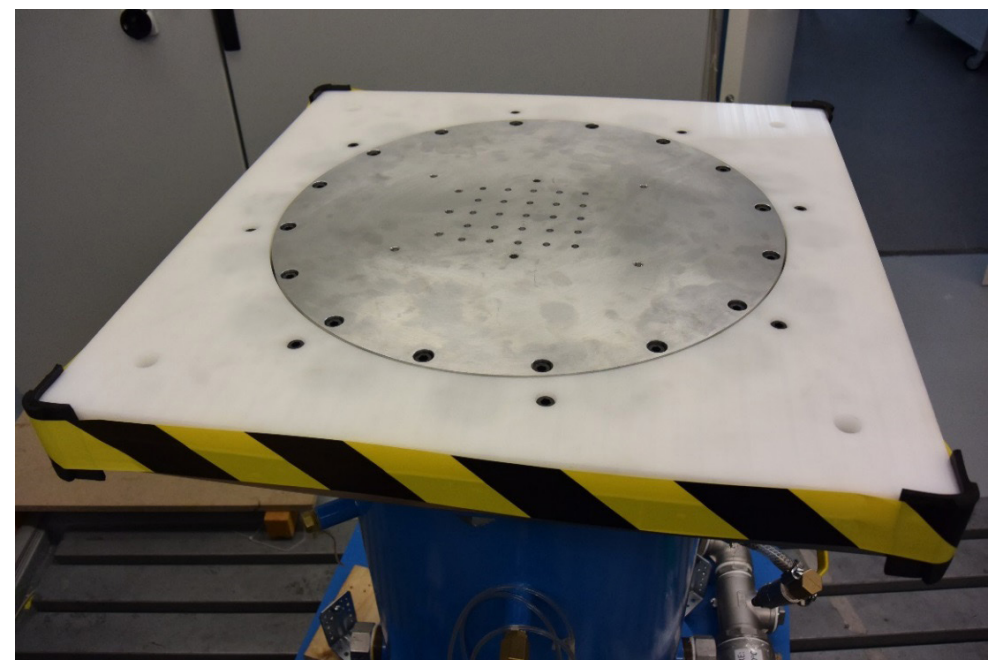

Fig. 7 Picture of a perforated plate mounted on a universal air supply vessel.

\subsection{Mathematical model used to describe the phenomenon of heat transfer at the test stand}

In order to determine the intensity of heat transfer, it is necessary to assume the physical heat exchange model that takes place in the case under consideration and to determine the dependence on the heat transfer coefficient. If a known heat release occurs in the tested object (e.g. due to the flow of electric current), then the temperature of the object rises to a level at which the heat transfer to the environment by means of convection, caused by temperature differences, will balance the heat source of a capacitive nature. Fig. 8 shows a heat transfer model for the heating foil. Cooling with impinging air jets takes place on the upper surface of the presented section with the heat transfer coefficient HTC, while on the lower side of the section the heat transfer takes place as a result of free convection with the heat transfer coefficient $\alpha$.
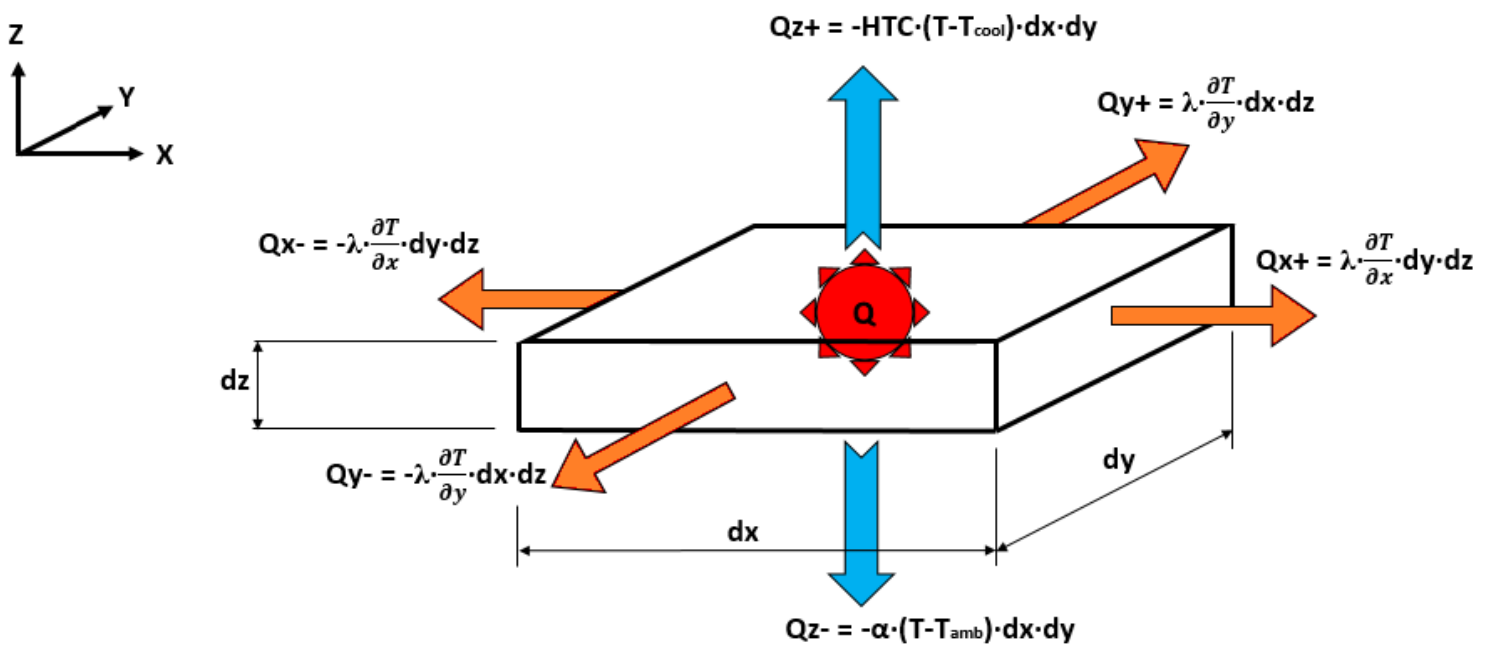

Fig. 8 Heat fluxes through a small segment of heating foil 
In the steady state, the algebraic sum of all heat fluxes must be zero. Neglecting the influence of radiation (relatively low temperatures of the test objects and separation of the test stand from the ambient radiation), the energy balance for a flat heating foil segment is (7):

$$
\mathrm{Q}_{(\mathrm{x}+)}+\mathrm{Q}_{(\mathrm{x}-)}+\mathrm{Q}_{(\mathrm{y}+)}+\mathrm{Q}_{(\mathrm{y}-)}+\mathrm{Q}_{(\mathrm{z}+)}+\mathrm{Q}_{(\mathrm{z}-)}+\mathrm{Q}=0
$$

After the synthesis of the equation we obtain a formula for the heat transfer coefficient (8):

$$
H T C=\frac{\eta \cdot I \cdot U}{\left(T_{\text {surface }}-T_{\text {flow }}\right) \cdot A}
$$

It follows from the above dependence that the key to determine HTC is to know the exact temperature distribution of the foil surface. Since it was assumed that the foil is thin and the temperature at a given point in the foil is constant along its thickness, the temperature can be measured both on the one side of the foil and on the other side, as $\partial \mathrm{T} / \partial \mathrm{z}=0$.

\subsection{Measurement data}

The example test was carried out on an unsupported foil (heater) for a mass flow rate of $23.0 \mathrm{~g} / \mathrm{s}$, which corresponded to approximately 1150 SLPM (standard litres per minute). For this flow, the Reynolds number was 10000 , the dew point was $-40^{\circ} \mathrm{C}$, and the reference temperature in the laboratory was $23.4^{\circ} \mathrm{C}$. The thermal conductivity of the air at the reference temperature is $0.0264 \mathrm{~W} / \mathrm{m}-\mathrm{K}$. The distance between the perforated plate and the test surface was $Z / D=5$, which with the diameter of the supply holes $\mathrm{D}=6.35 \mathrm{~mm}$ corresponded to the distance $\mathrm{Z}=31.75 \mathrm{~mm}$. The test was performed for four different values of electric heater power (200W, 300W, $400 \mathrm{~W}$ and $550 \mathrm{~W})$. This allowed to obtain sample temperature in the range of temperature sensitive paint operation $\left(20-90^{\circ} \mathrm{C}\right)$. In order to determine the temperature, we used our own calibration curve of the TSP paint.

Fig. 9 shows an example of temperature and the Nusselt number distributions for $200 \mathrm{~W}$ heater power.

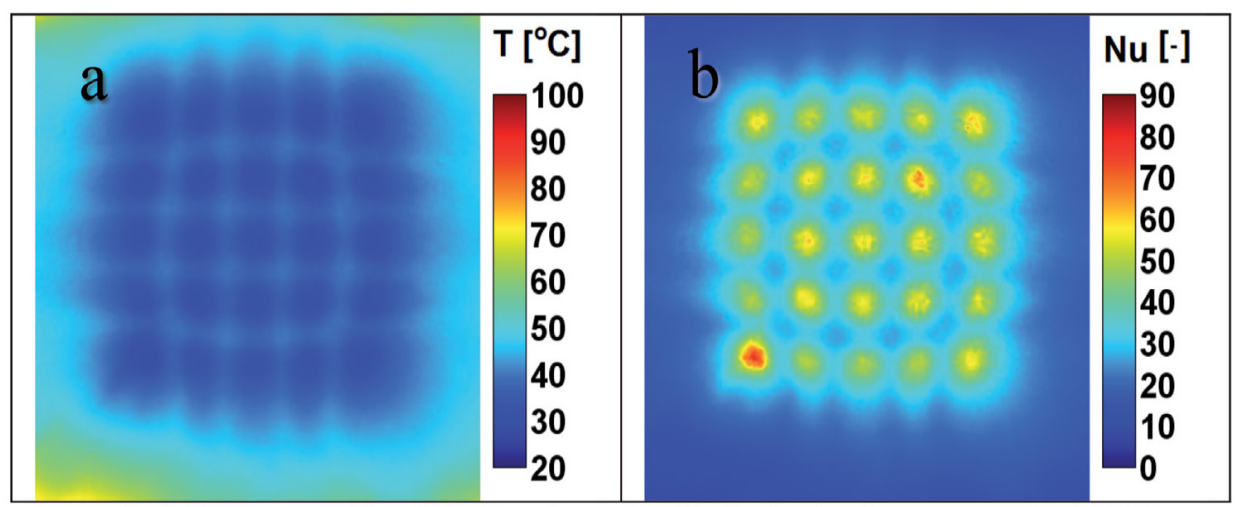

Fig. 9 Temperature (a) and the Nusselt number (b) distribution, heater power $\mathrm{P}=200 \mathrm{~W}$. 


\subsection{Discussion of the results obtained. Measurement uncertainty.}

Each measurement result should be accompanied by an uncertainty of measurement analysis in order to determine the correctness of the data obtained and to evaluate the method used. The heat transfer coefficient has been determined using following formula (9):

$$
H T C=\frac{\eta \cdot I \cdot R^{2}}{A \cdot\left(T-T_{a m b}\right)}
$$

where:

HTC $\left[\mathrm{W} / \mathrm{m}^{2}-\mathrm{K}\right]$ - heat transfer coefficient

I $[\mathrm{A}]$ - electric current, flowing in a circuit

$\mathrm{R}[\Omega]$ - heating system resistance

A $\left[\mathrm{m}^{2}\right]$ - heating foil area

$\mathrm{T}\left[{ }^{\circ} \mathrm{C}\right]$ - surface temperature

$\mathrm{T}_{\mathrm{amb}}\left[{ }^{\circ} \mathrm{C}\right]$ - Cooling air temperature, equal to ambient temperature

$\Delta \mathrm{X}$ - the predicted error of measurement of the X quantity

$\eta[-]$ - heat efficiency of the heating system

The uncertainty in determining the heat transfer coefficient is (10):

$$
\begin{aligned}
& \triangle H T C= \\
& \sqrt{\left(\frac{\partial H T C}{\partial A} \cdot \Delta A\right)^{2}+\left(\frac{\partial H T C}{\partial \eta} \cdot \Delta \eta\right)^{2}+\left(\frac{\partial H T C}{\partial R} \cdot \Delta R\right)^{2}+\left(\frac{\partial H T C}{\partial I} \cdot \Delta I\right)^{2}+\left(\frac{\partial H T C}{\partial T} \cdot \Delta T\right)^{2}+\left(\frac{\partial H T C}{\partial T_{a m b}} \cdot \Delta T_{a m b}\right)^{2}}
\end{aligned}
$$

The surface area of heater $A$ and the electrical efficiency $\eta$ have been determined with very high accuracy. For this reason, dependence (10) can be simplified to form (11):

$$
\Delta H T C=\sqrt{\left(\frac{\partial H T C}{\partial R} \cdot \Delta R\right)^{2}+\left(\frac{\partial H T C}{\partial I} \cdot \Delta I\right)^{2}+\left(\frac{\partial H T C}{\partial T} \cdot \Delta T\right)^{2}+\left(\frac{\partial H T C}{\partial T_{a m b}} \cdot \Delta T_{a m b}\right)^{2}}
$$

Since the surface temperature varies depending on the location on the foil, the measurement uncertainty can only be determined as the surface distribution. An example of such a distribution is shown in Fig. 10:

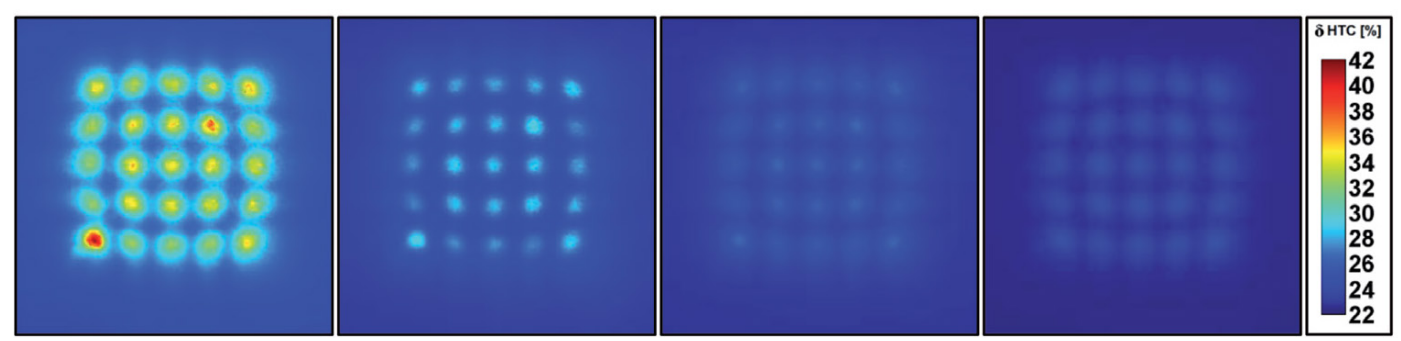

Fig. 10: Uncertainty distribution of the heat transfer coefficient (the Nusselt number) for a.) $200 \mathrm{~W}$, b.) $300 \mathrm{~W}$, c.) $400 \mathrm{~W}$ and d.) $550 \mathrm{~W}$. 
The presented distribution of uncertainty of heat transfer coefficient determination includes all uncertainties related to both the uncertainty of measurement of the heat flux supplied by the electric heater to the measuring station as well as all temperature errors related to the TSP methodology. Fig. 10 shows that the greater the uncertainty, the smaller the temperature differences are measured. Therefore, in order to achieve high accuracy, the entire measuring range of temperature sensitive paint should be used. The error rate for determining the heat transfer coefficient varies between $20-25 \%$ for the maximum permissible temperature differences.

Equation (9) assumes that there is no heat conduction on the inside of the heating foil (adiabatic wall). Taking into account the heat exchange due to natural convection, the additional error in determining the heat transfer coefficient is equal to the free convection heat transfer coefficient. This value is about $5-7 \mathrm{~W} / \mathrm{m}^{2}-\mathrm{K}$, which with measured values of $200-250 \mathrm{~W} / \mathrm{m} 2-\mathrm{K}$ is about $2-3 \%$ of the error.

\section{CONCLUSIONS}

By measuring the surface temperature distribution it is possible to determine the heat transfer coefficient with good accuracy. The obtained results are within the range obtained by other researchers. The measurement uncertainty also does not differ from the values provided by other researchers, which in the case of the new measurement technique proves both the accuracy of the method as well as its good mastery by the laboratory team.

In the future, research on a technique using measurements of transient heat conduction is planned. If this measurement technique is also mastered, it will be possible to study internal flows in a very wide range, due to the easy availability of an RGB camera that records visible light to the subject of the study (the inside of the channel), as well as the possibility of using commonly available and cheap materials for building models. Such tests would be very useful in determining the cooling efficiency of flow machines' channels as well as in checking for the presence of the boundary layer separation.

The high conductive core method can be used for heat flow through the surface of flying objects. Growing interest in rockets, which can be carriers for microsatellites, may be a stimulus to undertake this type of research in the future.

\section{BIBLIOGRAPHY}

[1] Liu, T. and Sullivan, J.P., 2005, Pressure and Temperature Sensitive Paints, Springer, New York.

[2] Jahanmiri, M., 2011, "Pressure Sensitive Paints: The Basics \& Applications," 2011:07, Chalmers University of Technology, Göteborg, Sweden.

[3] Cottingham, T., 2015, "Characterization and Optimization of Temperature-Sensitive Microbeads for Simultaneous Thermometry and Velocimetry for Fluid Dynamic Applications," M.Sc. thesis, University of Washington.

[4] Kurits, I. and Norris, J. D., 2011, "Temperature-Sensitive Paint Calibration Methodology Developed at AEDC Tunnel 9," AIAA 2011-851.

[5] Schramm, J.M., Hannemann, K., Ozawa, H., Beck, W. and Klein, Ch., 2014, "Development of Temperature Sensitive Paints for the High Enthalpy Shock Tunnel Goettingen," $8^{\text {th }}$ European Symposium on Aerothermodynamics for Space Vehicles, Lissabon.

[6] Szafran, K., Shcherbonos, O. and Ejmocki, D., 2014, "Effect of duct shape on ducted propeller trust performance," Transactions of the Institute of Aviation, No. 4 (237), pp. 85-91. 
[7] Ruchała, P. and Szafran, K., 2016, ”Praktyczne Aspekty Zastosowania Otunelowanych Śmigieł Pchających," (ang. The Aspects of Practical Application of Ducted Fans), Transactions of the Institute of Aviation, No. 3 (244), pp. 257-266.

[8] Navarra, K. R., 1997, "Development of the Pressure-Sensitive-Paint Technique for Advanced Turbomachinery Applications,” Ms.C. thesis, Virginia Polytechnic Institute and State University.

[9] Stokes, N., Patel, S. and Hahn, M., 2012, "Boundary Layer Transition Detection Using Temperature Sensitive Paint in the ARA Transonic Wind Tunnel," ICAS 2012-3.4.2, $28^{\text {th }}$ International Congress of the Aeronautical Sciences, Brisbane, Australia.

[10] Borovoy, V., Mosharov, V., Noev, A. and Radchenko, V., 2012, "Temperature Sensitive Paint Application for Investigation of Boundary Layer Transition in Short-Duration Wind Tunnels," Progress in Flight Physics 3, pp. 15-24.

[11] Rosłowicz, A. and Bednarczyk, P., 2017, "Analysis of Heat Transfer in a Supersonic Rocket Head," Transactions of the Institute of Aviation, No. 1 (246), pp.79-94.

[12] Zuniga, H. A., 2009, "Study of Film Cooling Effectiveness: Conical, Trenched and Asymmetrical Shaped Holes," Ph.D. thesis, University of Central Florida, Orlando.

[13] Wright, L. M., Gao, Z., Varvel, T. A., and Han, J.-C., "Assessment of Steady State PSP, TSP, and IR Measurement Techniques for Flat Plate Film Cooling," Heat Transfer: Volume 3, ASME, 2005, pp. 37-46.

[14] Crafton, J.W., 2004, "The Impingement of Sonic and Sub-Sonic Jets onto a Flat Plate at Inclined Angles," Ph.D. Thesis, Purdue University.

[15] Crafton, J., Ladchenko, N., Guille, M. and Sullivan, P., "Application of Temperature and Pressure Sensitive Paint to an Obliquely Impinging Jet," $37^{\text {th }}$ Aerospace Sciences Meeting and Exhibit, AIAA-99-0387, Reno, USA.

[16] Bell, J.H., 2004, "Applications of Pressure-sensitive Paint to Testing at Very Low Flow Speeds," AIAA-2004-0878.

[17] Fonov, S., Crafton, J., Goss, L., Jones, G., Fonov, S. and Tyler, C., 2005, "Multi-Aspect Solutions for Moving Vehicle Testing," RTO-MP-AVT-124-5, NATO Science and Technology Organisation.

[18] Liu, Q., 1993, "Study of Heat Transfer Characteristics if Impinging Air Jet Using Pressure and Temperature Sensitive

[19] Gao, L., 2003, "Effect of Jet Hole Arrays Arrangement on Impingement Heat Transfer," M.Sc. thesis, Louisiana State University.

[20] Sullivan, J., 2009, "Molecular Sensors - Temperature Sensitive Paint", https://slideplayer.com/ slide/1675994/ Luminescent Paint," Ph.D. thesis, Nanjing University of Aeronautics and Astronautics.

[21] Jeziorek, Ł., 2017, "Rozwój Metodologii TSP (Farba Termoczuła) i Potencjału Badań Laboratoryjnych z Nią Związanych,” (ang. Development of Thermal Sensitive Paint Methodology and Its Research Capabilities), Sprawozdanie z pracy badawczej nr 2017/PS/01, Institute of Aviation, Warsaw. 


\section{PRZEPŁYW CIEPŁA WYZNACZANY METODĄ FARBY TERMOCZUŁEJ}

\section{Streszczenie}

Artykuł przedstawia praktyczne aspekty wyznaczania ilości przepływającego ciepła za pomocą pomiaru rozkładu temperatury powierzchniowej metodą farby termoczułej (ang. Thermal Sensitive Paint - TSP). Wielkością mierzoną bezpośrednio przy użyciu TSP jest intensywność wzbudzonego promieniowania, która następnie jest przeliczana na temperaturę powierzchni. Artykuł przedstawia pokrótce trzy różne metody wyznaczania współczynnika przejmowania ciepła. Każda z tych metod bazuje na osobnym zestawie założeń i znamiennie wpływa na konstrukcję stanowiska pomiarowego. Zaletami każdej z przedstawionych metod są ich własności indywidualne, pozwalające na poprawienie dokładności, zmniejszenie kosztu badań lub możliwość zastosowania w testach obiektów o dużym stopniu skomplikowania. Dla każdej metody przedstawiono model matematyczny użyty do wyliczania współczynnika przejmowania ciepła. Dla metody testowej w warunkach ustalonego przewodzenia ciepła i użyciu grzałki o stałej i znanej wydajności cieplnej przedstawiono przykładowe wyniki badań własnych wraz z porównaniem wyników z dostępnymi danymi oraz dyskusją dokładności uzyskanych wyników.

Słowa kluczowe: farba termoczuła, TSP, pomiar temperatury, współczynnik przejmowania ciepła, HTC. 